\title{
TRANSACTIONS
}

\section{American Microscopical Society}

(Published in Quarterly Installments)

Vol. $\mathrm{xxxv}$

APRIL, 1916

No 2

THE INNERVATION OF THE AMPULLÆ OF LORENZINI IN ACANTHIAS VULGARIS

\author{
By Herbert Edmond Metcalf \\ Teaching Fellow in Animal Biology, University of Minnesota
}

\section{INTRODUCTION}

In a former paper (1914) the author gave a general description of the ampullæ of Lorenzini in Acanthias vulgaris, presenting evidence as to the sensory nature of these organs. Since that time further work has been done on their innervation and is embodied in this paper.

Peabody (1897) published a short article on the innervation of these structures as shown by methylin blue preparations, and the present author's findings as published in the 1914 paper closely agreed with his in the main, altho there was some doubt expressed at that time as to the nodules described being the actual termination of the nerve fiber. Later findings indicate that a complete impregnation was probably not present either in Peabody's preparations, or in the author's in 1914. Later methods have demonstrated the final terminations of the nerves supplying the ampullæ.

\section{Methods}

New material impregnated by the methylin blue method was sectioned, and several preparations were made by the Bielschowsky double silver and gold process. The results therefore, were checked 
up between those two methods, as well as by maceration and isolation of cells.

It was considered probable that if the nerves which supply the ampullæ terminate on particular cells in the ampullary pockets, isolation by means of maceration and teasing would be likely to show isolated sensory cells with their nerve terminations attached. Material was macerated in 3\% caustic potash for 24 hours, teased immediately in glycerine and mounted in glycerine jelly; or carried through the alcohols, teased in balsam and mounted. In this way thousands of isolated sensory cells were obtained as well as isolated supporting cells. This proved to be a very valuable method of studying the general structure of the epithelium as well as for the sensory cells with their nerve terminations.

\section{The Gross Innervation of An Ampulla}

There are eight definite groups of ampullæ in Acanthias; two on the dorsal surface, four on the ventral, and two on the lateral surfaces of the snout and head. As might be expected these groups are bilaterally symmetrical. The number in each group, however, varies somewhat and each ampulla has not a fixed position on each side. The position of four of these groups may be seen in Figure 2 (dorsal Fig. 2-A, ventral Fig. 2-C.) The two ventral groups have not yet been divided into four by the cartilege bars of the rostrum.

There are two kinds of ampullæ in Acanthias. Those with a single duct extending from the alveolar portion to the surface, and those with a split duct. As was explained in the previous paper these two types are essentially alike, only in the ampullæ which have a double duct there are no primary ducts, the division between the two secondary tubules being carried completely to the surface.

The model in Figure 1 (P1. XXII) was made from sections 5 microns thick by the wax plate method and shows approximately the size and shape of the ampullæ having a double duct. In this case an ampulla having a short duct leading to the surface was selected, in order that the entire course might be modelled. This particular ampulla had alveoli and does not follow an equal division 
into secondary and tertiary ducts. There are several alveoli which come off the main or secondary ducts. (Fig. 1-D.)

The external opening is nearly round and divided by the partition between the two secondary ducts. Immediately below the skin the duct widens out to about twice the size of the opening, and proceeds downwards to the alveolar portion. Here there is a sharp constriction to about seven eighths its size and then the alveoli are budded off at different levels. This fact is important for it can be readily seen that the number of alveoli cannot be counted from a single section, as they will not all be included. The average number of alveoli in the ampullæ of Acanthias is twentytwo. The model shows the general appearance and proportion faithfully with the exception that there is some slight shrinkage so that the alveoli in the fresh total mount are somewhat more rounded and not so long in proportion to their width. This is probably due to the coagulation of the mucus in the lumen of the ampulla due to the fixing fluid.

The ampullæ in the two groups on the dorsal surface of the snout are innervated by the ophthalmicus superficialis; those of the ventral groups by the buccalis; and those of the spiracular region by the mandibularis externus branches of the seventh or facial nerve. These branches also innervate the lateral line system in those regions. The ophthalmicus superficialis may be seen under the dorsal group in Figure 2-B, and the buccalis directly over the ventral group in Figure 2-D.

From the main nerve trunk as it passes along close to the alveolar portions of the ampullæ, there is given off a single twig to each ampulla containing from 5 to 15 medullated fibers. The number of medullated fibers does not correspond at all to the number of alveoli, altho in cases where there are a large number of alveoli there is a large number of fibers. Roughly speaking there are about twice as many alveoli as there are fibers supplying the ampulla. These twigs run to the ampulla, and as the alveoli are arranged in a circle, there is a central space into which the nerve twig runs. (Figs. 5 and 6.) This twig does not give off branches until it reaches a level just below where the duct begins and where the ampullary pockets are budded off. At this point the nerves bend laterally (Fig. 5-b) with respect to the ampulla, 
and radiate out between the alveoli close to where the alveoli join the duct. (Fig. 6.)

This radiation takes place practically at the same plane for all of the nerve fibers, and all turn at right angles to their first course in 15 to 20 microns.

While doing this, the nerve fibers, which have up to this time been medullated, lose their sheaths, and when they appear on the external surface of the ampulla, between the alveoli, they are entirely devoid of covering. (Fig. 3.) Thus it may be seen that the course of the neurofibrils over the ampullary pockets themselves is in the majority of cases, from the bases of the alveoli toward their distal ends, speaking in respect to the orientation as shown in the model. (Fig. 1.)

As the neurofibril reaches the external surface of the ampulla, it divides into a great number of neurofibrillæ which anastomose over the entire surface of the pockets making a network over that portion of the ampulla which is sensory in character. (Fig. 4.) Whenever two fibrillæ branch a spot or nodule is formed. Nodules are also often seen along the course of the fibrils, as well as where a fibril apparently ends. (These nodules are labelled $b$ in Figures 9 to 14.) These were taken by Peabody (97) and by the author (1914) to be the endings of the neurofibrils upon the bases of the sensory cells. This, however, I have now seen is not the case.

\section{Nerve Terminations}

The sensory cells in the epithelium are well seen both in sections and in isolated specimens, and are the large pear-shaped cells with broad bases and a short projection which extends out to the lumen of the ampulla. Each of these cells is surrounded by four or five supporting cells which fit over the top as shown in Figure 9. In macerated preparation the pear-shaped cell comes away from the supporting cells and leaves the small hole where its projection reached the lumen. (Figs. 7 -a and 8 -a.) The supporting cells in macerated preparations give a table-like appearance as shown in Figure 8, and they occasionally stick together as in Figure 7. Figure 9 is a drawing of a sensory cell complete with its four supporting cells and its nerve termination. All of these cells are more 
or less rounded due to the fact that they swell somewhat in the maceration process. This gives a more or less rounded appearance to their bases which appear flat in sections. Figure 10 is a drawing of an isolated cell which was cleared and drawn in optical section so as to show the small projection from its upper surface to the lumen.

The neurofibril, which has been traced to the small nodule on the base of the cell, does not stop there but has a small process extending up between the sensory cell and the interstitial cell. (Labelled $c$ Figs. 9-14.) This process does not readily impregnate with methylin blue but can be seen occasionally by very careful focussing with the oil immersion lens in cases where it does occur. It has been seen a sufficient number of times to justify the statement that in all probability all of the pear-shaped cells have such a termination. This process which was entirely overlooked in the previous paper, is the final termination of the nerve. This process arises from the nodule on the base of the cell and is very slender. It extends to the level of the lower border of the nucleus and there flares out with a fork and encloses an area which in my preparations appeared lighter than the rest of the nerve. It must be understood that this oval area is NOT on the inside of the cell, but closely applied to its external surface. This form of ending is much like the terminations of the sensory fibers in the ear of Mustelus as described by Morrill (97), and may be taken as evidence of the homology of these ampullæ with those of the ear.

In isolated sensory cells impregnated by the methylin blue method the cell may sometimes be seen with this process connected with the basal nodule as well as with part of the torn neurofibril. (Figs. 11 and 14.) Morrill (97) in his figures shows many cells which have no hairs, and yet were sensory in character. These cells in the ampullary pockets look somewhat like hair cells with the exception that the process is rather thick and does not project out into the lumen. In every case, however, it connected with the lumen. This is not as readily seen in sections as it is in isolated specimens, because in sections these sensory cells are so large that it is only occasionally that a section cuts the process exactly to show it extending to the lumen. In thick sections, by focussing, it may 
be recognized. It may thus be seen that the real termination of the nerve supplying the ampullæ of Lorenzini in Acanthias is a slender process extending from the basal nodule to a point about half way up on the cell, and there flaring out into an oval plate in close contact with the sensory cell.

\section{SUMMARY}

1. Each ampulla is innervated by 5 to 15 medullated fibers from the seventh or facial nerve.

2. These fibers run into the central space of the ampulla, turn sharply and radiate laterally to reach the external surface of the ampulla.

3. From there they radiate downwards forming a network with nodules on the bases of the sensory cells.

4. The termination in Acanthias vulgaris is a light oval plate closely applied to the sensory cell at about its middle and connected with the basal nodule by a slender strand.

I wish to thank Dr. J. B. Johnston for his kind help during the course of this investigation.

\section{BIBLIOGRAPHY}

1678. Lorenzini, Stephan-Osservazioni intorno alle Torpedini. Florence. 1897. Morrill, A. D.-The Innervation of the Auditory Epithelium of Mustelus canis (de Kay). Journ. Morph. Vol. XIV, No. 1.

1897. Peabody, J. E.-The Ampullæ of Lorenzini of the Selachii. Zool. Bull. Vol. 1, No. 4.

1898. Forsell, Gustav--Beiträge zur Kenntniss der Lorenzinischen Ampullen bei Acanthias vulgaris. Zeitsch. f. Wissensch. Zool. Vol. 65.

1910. Parker, G. H.-The Influence of the Eyes, Ears, and Other Allied Sense Organs on the Movements of the Dogfish Mustelus canis (Mitchel). Bull. of the U. S. Bureau of Fisheries, Vol. 29.

1914. Metcalf, H. E.-The Ampullæ of Lorenzini in Acanthias vulgaris. Trans. Am. Microscop. Soc. Vol. XXXIV, No. 2. 



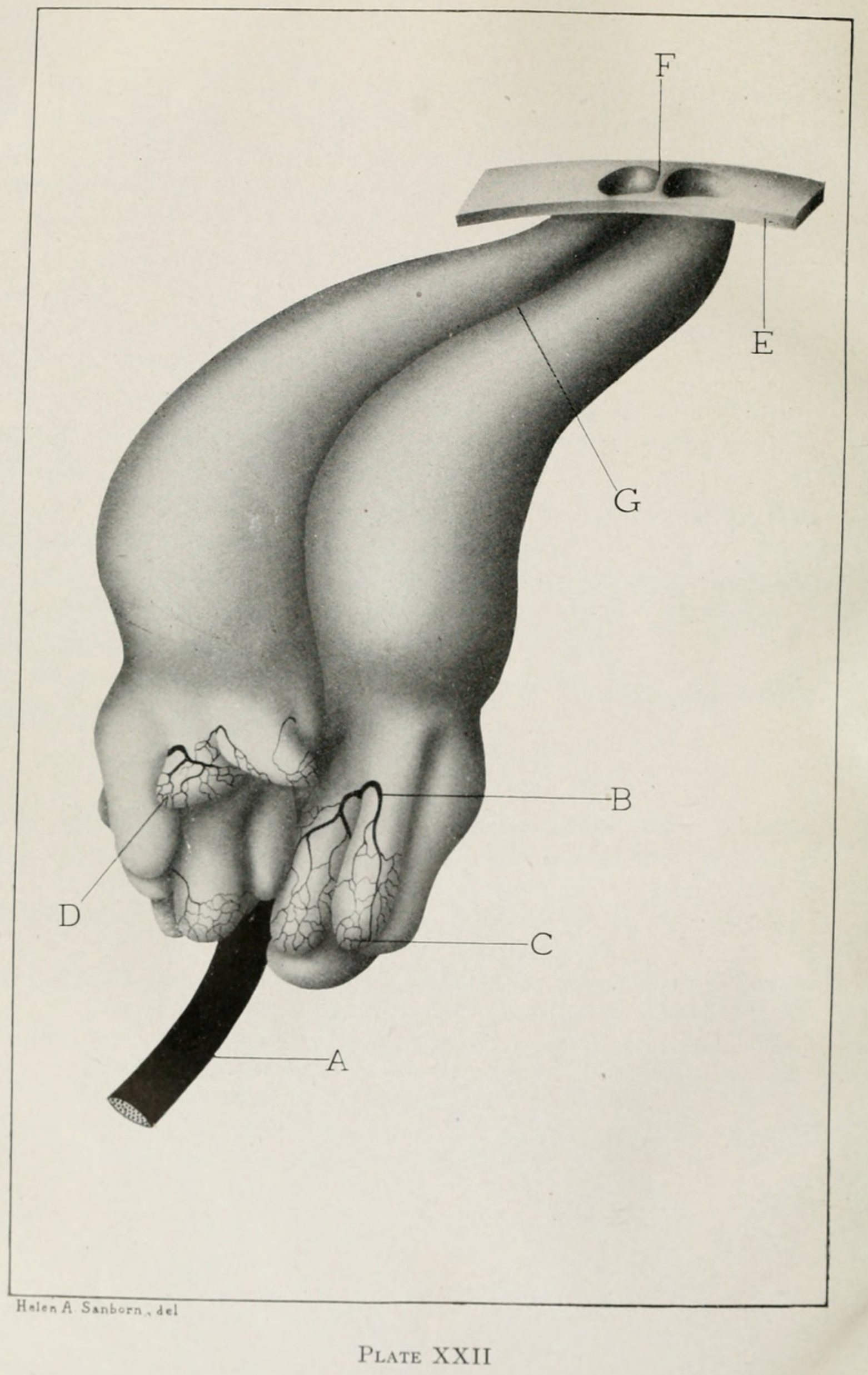




\section{$2 \mathrm{BHL}$ Biodiversity Heritage Library}

Metcalf, Herbert Edmond. 1916. "The Innervation of the Ampullæ of Lorenzini in Acanthias Vulgaris." Transactions 35, 167-174.

View This Item Online: https://www.biodiversitylibrary.org/item/86817

Permalink: https://www.biodiversitylibrary.org/partpdf/90988

\section{Holding Institution}

University of Toronto - Gerstein Science Information Centre

\section{Sponsored by}

University of Toronto

\section{Copyright \& Reuse}

Copyright Status: Not provided. Contact Holding Institution to verify copyright status.

This document was created from content at the Biodiversity Heritage Library, the world's largest open access digital library for biodiversity literature and archives. Visit BHL at https://www.biodiversitylibrary.org. 